\title{
The Building Blocks That Lead to Higher Education: Programs Provide Direction Behind Prison Walls Wilfredo Laracuente
}

$\mathrm{T}$ he pursuit of higher education in prison is a complex combination of thoughts, perceptions and fortitude. You have a large populace that exists within the confines of the prison walls who are muddling around aimlessly, biding time until their release dates become a reality or not. Those who act contrary to this ethos and custom of prison life are ridiculed and criticized. Similar to Hippocrates on a witch-hunt willing to charge anyone and everyone, a minority struggles to break from the prison norms.

The minority are men who constructively utilize their time to empower themselves with substance and knowledge vital for life post-incarceration. This drive for change is a fuel that ignites within the person like pitch from a tree. This change often does not begin with higher education. Volunteer therapeutic programs provide insight, sparking critical thinking and contemplation of self. Some men who participate in these programs find the courage to speak in an open forum for the very first time about their experiences that have never been explored. Comradery often develops within this peer system and men become support systems for one another. Collectively they can relate to each other, and become invested in themselves and others through attributes like integrity of character and self-worth. They begin to understand the deficiencies that led to their social, emotional, and cognitive development, which translates into a willingness to learn and explore alternative methods of problem solving. For many, it is the first time a comfortable atmosphere becomes a possibility. Prison does not cultivate comfort under any circumstances. Incarcerated people are subjected to endless repetition, including being counted at specified times throughout the day. Facility movements reoccur like clockwork, down to the synchronized second. Programming, recreation and exercise break up the monotony a little, but ultimately after a few years, they too become mundane. Mental conditioning and resolve are necessary attributes to help break free from the prison routine that hinders growth. Education and selfawareness can invoke a paradigm shift that alters "the routine", acting as stepping-stones to enable and provoke success.

As participants continue to work on themselves, they develop a skillset that includes organizational skills, improvisational competence, public speaking and an investment in helping others change. "When educators know that a constituency has no ability to challenge how it is being served, 
where does the incentive come from to serve it well?" (Noguera, 2008, p. 75). Individuals from all walks of life, whether through sharing personal experiences or showcasing their success stories, have become - as a direct result of the program - what fuels the drive to change.

The Osborne Association was my first experience at volunteer therapeutic programming. Osborne is a non-profit organization funded by the New York State Department of Corrections and Community Supervision to provide and strengthen family services inside select correctional facilities. Until experiencing this program, I did not tackle the issues that were holding me back from becoming a better father. I was able to make peace with the anger I felt for my own father abandoning my mother and I at an early point in my childhood. This opened a plethora of communication, understanding, and trust between my family members and I, especially my daughters, and I became relevant in the lives of my children.

I also discovered a newfound confidence that enriched my existence and that led to other opportunities. Public speaking became a niche that I discovered I was very good at. Upon completing the program, I was asked to emcee and give a speech at the 2012 Osborne Graduation. A few months later, the Family Service Specialist asked if I was willing to work for the organization as an administrative clerk and caregiver. For the past four years I have worked closely with the Osborne staff as the primary caregiver in their in-prison Family Center at Sing Sing Correctional Facility. I give up many Saturdays, Sundays, and holidays to ensure that children who are visiting their fathers, grandfathers, brothers, or other relatives can do so in a child-friendly, non-threatening environment that helps to strengthen the family relationships and the efficacy of the children. In addition, I have created a curriculum for a pilot program called Fatherhood Forum on behalf of the Osborne Association. This forum meets four times a year and is cofacilitated by me in concert with Osborne staff. Educational experiences come in all shapes and sizes during incarceration and had it not been for this first stepping-stone I would not have been able to quantify the impact this program has had on me.

All men, regardless of circumstance, deserve an opportunity to live instead of merely existing. Taking advantage of the opportunities presented before me dismantles incarceration and generates a turning point. Through programming, I discovered the potential to make a difference. Once I began to view life differently, taking advantage of the college experience 
seemed normal. Learning the power of words and developing a command of language became important. Frankly speaking, I no longer want to be perceived in a negative light. I want an accurate depiction of a constructive individual with the ability to excel and wholeheartedly accomplish anything I transfix my mind to. Complacency can easily enter the equation if one is not careful behind these prison walls. Remaining grounded in this environment is a delicate balance for most. "Stay hungry, remain humble, keep inventing and hone your craft" are words to live by to achieve your educational goals.

Thinking outside the box and stepping outside of your comfort zone are lynchpins vital in maximizing the opportunities in education while incarcerated. Everyone has something they do better than most and "that something" should become their focal point. The narrower the range, the more likely success is the inevitable outcome. My participation with the Council for Unity is what propelled me to venture out of my comfort zone. Based on the concept of Family, Unity, Self-esteem and Empowerment (FUSE), one of the aspects of the program encouraged introspection in ways that I had never explored before. I was asked, "What did you not accomplish?" I sat in my prison cell contemplating a response disentangled from pride and ego. I responded:

Throughout my life prior to incarceration, I had many opportunities. Whether it was in the realm of education, employment, relationships, or other areas. I felt any set back could be corrected because I did not foresee incarceration and squandered the possibility of a college degree. I failed at the opportunity to be a great father to my two daughters through my incarceration. I fell short of what a man should be for his family as set by the men in my life - such as my step-father, uncle, godfather, and grandfather. I could honestly say that I did not believe I had accomplished anything prior to my incarceration.

When I closed that portion of my journal, I had a realization and made the conscious decision to bring peace to whatever chaos occurred in my life, to refuse to allow the past to consume me, and to use my newfound passion to make me whole. I started to participate more in the discussion portion of the program and to establish my personality within the group. After completing the program, I was asked to partake in facilitator training and to start disseminating the curriculum to men in the prison population 
with the hope of becoming an integral part of their transformation just as the program had done for me.

In prison, education is a journey. It stems from an instance where a switch turns on and suddenly one finally gets the gist. After sampling a glimpse of the new you, this sudden yearn to achieve another goal becomes an incredible motivator. Education is not limited to an institution of higher learning. Individuals enveloped in the educational experience transform themselves into role models who influence and provide hope to others that they too can achieve higher education. In turn, new minded men become attuned to new ideas and programs that improve the overall living conditions in prison. That is why it is imperative to expose as many prisoners as possible to the college experience, bolstering the chances of potential students who may be teetering on the fence in contemplating whether or not to apply.

As time passed, networking became the goal and I began to rub elbows with men who possessed similar interests and traits. The majority of the prison population misunderstands this fraternity as it challenges the norms of the prison that are contrary to the natural pecking order. In prison, I learned that if an issue does not concern you directly, you must choose to ignore it and concentrate on the things that do.

I later learned that the Mercy College Hudson Link Program was holding tryouts for a TEDx Talk event titled, TEDx Sing Sing. The subject matter was a three-minute talk on "healthy communities" and try-outs were open to anyone in the prison population. The talks were based on content, originality, presentation and public speaking. Those selected for the TEDx Event would have their talks filmed and streamed online. This was an opportunity that I did not want to miss. "Would I be able to pull this off?", I asked myself. "Maybe this is not for me?" "Will I make a fool of myself?" Those were questions I repeatedly asked as I developed the content of my presentation.

I chose to discuss the idea of exposing young men at an earlier age to the importance of fatherhood. The title of my Ted Talk was "A Good Role Model of What Not to do". I was one of the eight men selected to speak on 4 December 2014. ${ }^{1}$ It was an epic event and I savoured the accomplishment. After the event, it was the first time I heard my mother say, "I am so proud of you. It's great to finally meet the man I knew you could always be". Those words remain a rallying support whenever I need to recharge, refocus and reach my next goal. 
I was then accepted to enroll in the Mercy College Hudson Link Program. I now long for these opportunities, where I once used to wander around prison aimlessly unable to place a finger on what I was going to do for the next twenty years of my prison stint. I am guilty of having cawed at others who carried books, schoolwork and program materials. Prison infuses a mentality and perception of hopelessness that makes it hard to sway from "the routine". Ironically, a man's greatest obstacle is his undisciplined self that most often only education can change. One of the great crimes of oppression is that it suspends your ability to dream. Education is a door and we must find it within ourselves to invest in our futures, develop confidence in our abilities, and understand our self-worth.

\title{
ENDNOTES
}

1 This $T e d X$ talk can be found on YouTube at https://www.youtube.com/watch?v= b3tPitKP0KA

\section{REFERENCES}

Noguera, Pedro N. (2008) "Standards for What? Accountability for Whom? Rethinking Standards-Based Reform in Public Education", in Kenneth A. Sirotnik (ed.), Holding Accountability Accountable: What Ought to Matter in Public Education, New York: Teacher's College Press - Columbia University, pp. 66-81.

\begin{abstract}
ABOUT THE AUTHOR
Wilfredo Laracuente was born and raised in Bronx, New York. This is his fifteenth year of incarceration on a twenty-to-life prison stint. He was recently accepted to enroll in the Mercy College Hudson Link Program.
\end{abstract}

